PRZEGLĄD NAUK HISTORYCZNYCH 2017, R. XVI, NR 2

http://dx.doi.org/10.18778/1644-857X.16.02.06

DARIUSZ JEZIORNY

UNIWERSYTET ŁÓDZKI*

\title{
Państwa sukcesyjne Austro-Węgier w dyplomacji polskiej (1918-1920)
}

Streszczenie. Austria, Węgry, Czechosłowacja, Rumunia i Królestwo SHS, a także Polska to państwa nazywane krajami sukcesyjnymi monarchii habsburskiej, ponieważ powstały na jej gruzach. Artykuł koncentruje się na znaczeniu tych środkowoeuropejskich państw w dyplomacji polskiej w latach 1918-1920, czyli w okresie decydujacym dla ich niepodległego bytu. Celem artykułu jest odpowiedź na pytanie o to, jak postępujący rozpad Austro-Węgier w roku 1918 był postrzegany przez polskie elity polityczne. W następnej kolejności istotne jest pytanie, jakie było stanowisko rządu niepodległego państwa polskiego wobec państwowości tworzacych się po rozpadzie monarchii Habsburgów. Pod uwagę wzięte zostały wszystkie kraje, które w całości lub w znaczącej części zagarnęły tereny austro-węgierskie. Pośród nich wyjątkiem są Włochy. Rzym zaanektował również znaczące tereny habsburskie nad Adriatykiem, ale już wcześniej był uznawany za jedna $z$ ważniejszych stolic europejskich i nowe nabytki jedynie zwiększyły jego potencjał. Istotne jest również zauważenie, czy omawiane państwa odgrywały jakąś rolę w polskiej polityce zagranicznej, a jeśli tak, to jak znaczacą. Podobne pytanie dotyczy całego terytorium Europy naddunajskiej. Jego polityczna i ekonomiczna jedność została zerwana po I wojnie światowej, co mogła wykorzystać rodzaca się Rzeczpospolita, mając do czynienia ze słabszymi od siebie potencjalnie partnerami.

Słowa kluczowe: dyplomacja polska, państwa sukcesyjne Austro-Węgier, obszar naddunajski.

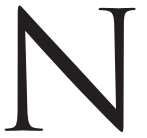

azwą „państwa sukcesyjne” określa się w historycznej literaturze przedmiotu te kraje Europy Środkowo-Wschodniej, które zbudowane zostały na gruzach monarchii habsburskiej. Nie każdemu nazwa ta się podoba. Przykładowo: Czecho-

*Wydział Filozoficzno-Historyczny, Instytut Historii, Katedra Historii Powszechnej Najnowszej, e-mail: dariuszjeziorny@uni.lodz.pl. 
słowacja nie chciała uchodzić za „sukcesora” Austro-Węgier. Tym niemniej określenie wydaje się zgrabnym i krótkim ujęciem tworzących się tzw. państw narodowych, co również nie jest nazwą precyzyjna w przypadku Polski, Czechosłowacji, Węgier, Rumunii czy Królestwa Serbów, Chorwatów i Słoweńców (dalej: Królestwo SHS). Najlepiej odpowiada ona międzywojennej Austrii, stanowiącej niemieckojęzyczna pozostałość po wielowiekowej monarchii.

Gdy chodzi o podjęte w tekście lata, to cezurę początkową uzasadnia zarówno rozpad Austro-Węgier w listopadzie 1918 r., jak i powstanie niepodległej Polski. $Z$ kolei wybór daty końcowej spowodowany był mniej wyrazistym argumentem, aczkolwiek istnieje kilka przesłanek na rzecz takiej decyzji. Po pierwsze, Polska zakończyła walki z bolszewikami. Mogła więc skoncentrować swoją uwagę na innych swoich granicach poza zachodnia i wschodnia. Po drugie, Węgry podpisały i ratyfikowały traktat w Trianon, co zakończyło niepewność co do tego, jak ostatecznie wyglądać będzie kraj nawiązujący do tradycji Korony św. Stefana. Wiazało się $z$ tym wyklarowanie się polityki Francji wobec obszaru naddunajskiego - nie było już wątpliwości, że Paryż nie postawi na Węgrów, lecz na państwa, które zaczęły formować w czerwcu 1920 r. Mała Ententę. W Austrii kończył się akurat pierwszy okres rządów republikańskich i po październikowych wyborach parlamentarnych socjaldemokraci utracili pierwszoplanową rolę. Jak się później okazało, w okresie międzywojennym nie odzyskali już władzy.

Celem artykułu jest odpowiedź na pytanie o to, jak polskie elity polityczne odnosiły się do rozpadu Austro-Węgier w roku 1918, a następnie, jakie było stanowisko kolejnych polskich rządów wobec państw tworzacych się na gruzach dualistycznej monarchii. Brane pod uwage sa wszystkie kraje, które włączyły pod swoja suwerenność poważniejsze tereny austro-węgierskie, czyli Austria, Czechosłowacja, Węgry, Rumunia i Królestwo SHS. Istotne będzie również zauważenie, czy wymienione państwa odgrywały jakąkolwiek rolę w polskiej polityce zagranicznej, a jeśli tak, to jaką. Podobne pytanie można by zadać w przypadku całego terytorium Europy naddunajskiej.

W okresie toczących się od 1914 r. walk sprawa rozpadu Austro-Węgier została zauważona przez polskie środowiska polityczne wiosna 1918 r. Jako pierwszy do problemu odniósł się Komitet Narodowy Polski w kwietniu 1918 r. przy okazji zorganizowanego w Rzymie przez rządy Ententy Kongresu Narodów Uciśnionych. 
Roman Dmowski i grono jego współpracowników solidaryzowało się $z$ uchwałami podjętymi na rzymskim spotkaniu, mającymi na celu osłabienie związków narodów, podporządkowanych do tej pory Niemcom i Węgrom. Przygotowali je zresztą u boku Francuzów wraz z przedstawicielami Czechów i Słowaków, Słowian Południowych i Rumunów ${ }^{1}$. Kolejna okazją do zamanifestowania swojego negatywnego stosunku do monarchii habsburskiej było poparcie dla uznania przez rządy państw Ententy niepodległości Czechosłowacji. Czechosłowacka Rada Narodowa działajaca na Zachodzie uzyskałaby uznanie jako reprezentant Czechów i Słowaków oraz zwierzchnik 50-tysięcznego Korpusu Czechosłowackiego, operującego wówczas na Syberii. Musiałoby to być jednoznaczne $z$ wyzwoleniem się Pragi spod zależności od Wiednia, a w tej sytuacji sama geografia sprawiałaby, że Galicja nie mogła mu również podlegać ${ }^{2}$. Trzecią okazja do wsparcia ruchów odśrodkowych w Austro-Węgrzech była nota pokojowa państw centralnych ogłoszona 4 października 1918 r. Minister István Burián prosił w niej prezydenta USA Thomasa Woodrow Wilsona o rozpoczęcie negocjacji pokojowych na terenie państwa neutralnego ${ }^{3}$. Komitet Narodowy Polski piętnował wówczas fałszywe obietnice władz austro-węgierskich co do przekształcenia dualistycznego ustroju w federacyjny. Wraz z przedstawicielami trzech innych narodów uciskanych, zamieszkujaccych monarchię Habsburgów, protestował przeciwko „aktowi dyplomatycznej hipokryzji”, jak nazwano krok Buriána, a także opowiadał się za niepodległością Polski. Wyrażał jednocześnie zaufanie do „poczucia sprawiedliwości narodów Ententy”, które „po okazaniu słabości przez państwa centralne” doprowadza do swojego „oswobadzającego zwycięstwa"4.

1 O niepodległa i granice. Komitet Narodowy Polski. Protokoły posiedzeń 19171919, oprac. M. Jabłonowski, D. Cisowska-Hydzik, Warszawa-Pułtusk 2007, s. 216, 286, protokoły z posiedzeń KNP z 14 XII 1917 i 28 II 1918 (zał. 4).

2 D. Perman, The Shaping of Czechoslovak State. Diplomatic History of the Boundaries of Czechoslovakia, 1914-1920, Leiden 1962, s. 37-44; H. Parafianowicz, Czechosłowacja w polityce Stanów Zjednoczonych w latach 1918-1933, Białystok 1996, s. 50-57.

${ }^{3}$ W. Fest, Peace or Partition. The Hapsburg Monarchy and British Policy. 1914-1918, London 1978, s. 251-252. Treść noty została zawarta już w przemówieniu Buriána z 10 IX, opublikowanego w krakowskim „Czasie” z 11 IX (wyd. poranne) 1918 , s. 1.

4 O niepodległa i granice..., s. 576-577, projekt deklaracji czterech komitetów narodów uciskanych przez Austro-Węgry, Paryż 10 X 1918. 
Z kolei Rada Regencyjna działająca w Warszawie nie mogła sobie pozwolić na tak daleko idąca szczerość, gdyż utrzymywała oficjalne stosunki z Wiedniem. Co prawda 7 października 1918 r. ogłosiła niepodległość Polski, deklarując, że kraj ten miałby się składać $z$ terytoriów zamieszkiwanych przez Polaków. Był to krok niewątpliwie wymierzony przeciwko Austro-Węgrom, ponieważ dwuznacznie sugerował oderwanie spod suwerenności Galicji. Nie miał on jednakże nic wspólnego w swoim wyrazie $z$ radykalna zmiana frontu Rady i zerwaniem relacji $z$ Wiedniem. Mogło o tym świadczyć notyfikowanie wobec monarchii naddunajskiej powstania 23 października rządu Józefa Świeżyńskiego ${ }^{5}$. Już sam ten fakt świadczyć musiał o dużej ostrożności polityków działających w Warszawie.

Ostatnie liczace się w tym czasie środowisko polityczne związane było $z$ Józefem Piłsudskim. Ten jednakże nie miał szans ustosunkować się do rozpadu Austro-Weggier, ponieważ w trakcie dokonywania się tego procesu, jak się okazało, krótkiego w czasie, siedział jeszcze w więzieniu. Powrócił do Warszawy 11 listopada, gdy monarchia habsburska już nie istniała. Jednakże jego dymisja $z$ Legionów 26 września 1916 r. oznaczała zerwanie $z$ okupantami Królestwa Polskiego, szczególnie z Austro-Węgrami. Piłsudski poparł wprawdzie akt 5 listopada, gdyż pozwalał on skoncentrować się na wojskowej stronie kontaktów $z$ państwami centralnymi, lecz miał świadomość, że Wiedeń coraz mniej znaczył w rozwiązywaniu sprawy polskiej. Kolejne wydarzenia doprowadziły do kryzysu przysięgowego, który zaowocował jego uwięzieniem. Nietrudno było więc zauważyć ewolucję jego postawy, prowadzącej do porzucenia nadziei związanych $z$ Wiedniem ${ }^{6}$.

Recepcja roli państw sukcesyjnych w polityce rządu polskiego po powstaniu niepodległych i suwerennych władz przedstawiona zostanie oddzielnie dla każdego $z$ nich. W pierwszej kolejności warto się skupić na republikańskiej Austrii. Był to kraj niegraniczący bezpośrednio $z$ Polska, ale na pewno bardzo Warszawę interesujący. Przedstawiciele polscy donosili na bieżąco o dramatycznej sytuacji społecznej: rewolucyjnych nastrojach ludności, w tym rozruchach głodowych w większych miastach, demonstracjach bezrobotnych

5 J. Pajewski, Odbudowa państwa polskiego 1914-1918, Warszawa 1985, s. 272, 278-280.

6 J. Lew a nd ow s ki, Królestwo Polskie wobec Austro-Wegier 1914-1918, Warszawa-Łódź 1986, s. 105, 116-118; R. Świętek, Lodowa ściana. Sekrety polityki Józefa Piłsudskiego, 1904-1918, Kraków 1998, s. 813-814, 818-820. 
i bezdomnych, anarchii i chaosie organizacyjnym. Towarzyszyła temu całkowita zapaść finansów publicznych. Nie było $z$ czego pokrywać bieżących wydatków publicznych i władze musiały ratować się drukiem pustych banknotów. Powodowało to szybki spadek wartości korony, co zwiastowało bankructwo tworzącego się państwa. Terytorialnie był to kraj, który pozostał po odebraniu przez sąsiadów ziem spornych. Na przyszłość trudno więc było marzyć o zrównoważeniu budżetu przez wpływy z podatków - przy ograniczeniu terytorium Austrii do ziem zamieszkałych przez Niemców $\mathrm{i}$ to tylko tych $\mathrm{w}$ pobliżu Wiednia oraz $\mathrm{w}$ prowincjach alpejskich pozostawało 6-6,5 mln mieszkańców, z czego $2 \mathrm{mln}$ w samej stolicy. W preliminarzu budżetu na rok 1919 przewidywano 2,5 mld koron deficytu, a ostatni deficyt całej monarchii wynosił 1,89 mld. W połowie roku 1919 prognozowano już 8 mld deficytu, a rok później było to 20-26 mld koron. Drastyczne i jednocześnie rozpaczliwe środki podejmowane przez resort finansów dla przysporzenia państwu dochodów nie były w stanie dokonać cudu utrzymania wypłacalności kraju. Odziedziczony po Austro-Węgrzech dług, olbrzymi po wojnie, również obciążał Wiedeń, ponieważ inne państwa sukcesyjne nie chciały go spłacać. Do bankructwa finansów publicznych dochodził brak żywności i węgla na opał, szczególnie w dużych miastach. Zarówno artykuły spożywcze, jak i węgiel uchodziły za towary luksusowe. Ich brak nie był zreszta nowy - ludność borykała się $z$ tym problemem już przez cały 1918 r. Tak beznadziejna sytuacja wewnętrzna Austrii rodziła napięcia polityczne, pogłębiane sporem o to, co zrobić $z$ przyszłościa kraju. W grę wchodziła kwestia Anschlussu do Niemiec, popierana przez socjaldemokratów i wszechniemców, lub odnowienie relacji z narodami współtworzącymi dotąd monarchię habsburską. Tę drugą opcję coraz odważniej głosiła Partia Chrześcijańsko-Społeczna. Idei niepodległej Austrii nikt nie głosił, mając świadomość niewydolności gospodarczej kraju. Jednakże forsowane koncepcje były ze soba nie do pogodzenia $z$ oczywistych względów ${ }^{7}$.

7 D. J eziorny, Austria kanclerza Karla Rennera (1918-1920) w raportach polskich dyplomatów i wojskowych, [w:] Austria i relacje polsko-austriackie w XX i XXI wieku. Polityka - kultura-gospodarka, red. A. Kisztelińska-Wegrzyńska, K.A. Kuczyński, Łódź 2014, s. 69-71; raport sytuacyjny E. Parnesa (kierownik Biura Prasowego przedstawicielstwa polskiego w Wiedniu) z 11 II 1919, Archiwum Akt Nowych w Warszawie [dalej: AAN], Komitet Narodowy Polski [dalej: KNP], teczka 50, k. 64-69, 72-73; referat informacyjny Naczelnego Dowództwa Wojska Polskiego [dalej: WP] z 1 XII 1920, AAN, Ministerstwo Spraw Zagranicznych [dalej: 
Z punktu widzenia Warszawy oba rozwiązania proponowane przez partie austriackie były przyjmowane niechętnie. Anschluss wzmacniałby Niemcy, a był to przecież niebezpieczny dla polskiej niepodległości i suwerenności terytorialnej sąsiad, dążący do odwrócenia poniesionych po I wojnie światowej strat terytorialnych. Ponadto przyczyny komunikacyjne nakazywały zabiegać o niezależność republikańskiej Austrii. Przez nią, Czechosłowację i Szwajcarię możliwe było połączenie kolejowe $z$ Francja, które omijałoby Niemcy. Ze względów strategicznych była to istotna przesłanka dla bezpieczeństwa kraju. Dnia 31 grudnia 1919 r. przedstawiciele rzadów Polski i Austrii podpisali szczegółowe porozumienie o tranzycie pociagów na trasie Francja-Polska przez Austrię. Jak się jednak okazało w czasie zbliżania się bolszewików pod Warszawę latem 1920 r., nadzieje na tego typu tranzyt okazały się płonne $z$ powodu ogłoszenia przez rząd czechosłowacki neutralności. Co więcej, Praga namówiła do podobnej deklaracji Austrię. Zatem szlak przerzutu ewentualnej pomocy do Polski z pominięciem Niemiec okazał się po 9 sierpnia 1920 r. nierealny ${ }^{8}$.

Mniej istotnym elementem, choć także pojawiającym się w rozważaniach polskich dyplomatów, była kwestia ulokowania się w Wiedniu władz Zachodnioukraińskiej Republiki Ludowej (dalej: ZURL), zdecydowanie wrogo nastawionych wobec Warszawy po porażkach w Galicji Wschodniej. Wcześniej już próbowano propagować na Zachodzie tezę, że to oficerowie austriaccy podpuścili Ukraińców na Polaków, $z$ czego wyniknęły krwawe walki o Lwów. Brak reakcji Wiednia na działania emigracyjnych władz ZURL mógł uzasadniać walkę strony polskiej jako część zmagań obozu Ententy $z$ wrogami ${ }^{9}$.

MSZ], teczka 215, k. 40-41. Gustav Stolper (Deutsch-Österreich als Sozial- und Wirtschaftsproblem, Wien 1921, s. 34) uważa, że deficyt w pierwszej połowie 1919 r. wyniósł aż 10 mld koron, czyli więcej, niż podawali polscy dyplomaci.

${ }^{8}$ E. Piltz (przedstawiciel KNP przy rządzie francuskim) do francuskiego MSZ, Paryż 27 XII 1918, Polskie dokumenty dyplomatyczne 1918: listopad-grudzień [dalej: PDD 1918], red. S. Dębski, Warszawa 2008, s. 369-370; J. Leśniewski (generał-porucznik, minister spraw wojskowych w rządzie I. Paderewskiego) do Paderewskiego (premier Polski), Warszawa 1 IV, Archiwum Polityczne Ignacego Paderewskiego [dalej: APIP], t. II, oprac. W. Stankiewicz, Warszawa 1976, s. 76; tekst porozumienia z 31 XII 1919, AAN, Attachaty, AII/56, k. 304-312; A. Essen, Polityka Czechosłowacji w Europie Środkowej w latach 1918-1932, Kraków 2006, s. 45-47; S.M. Nowinowski, Konstatacje $i$ nadzieje. Dyplomacja czechosłowacka wobec kwestii bezpieczeństwa zbiorowego w Europie (1918-1925), Torun 2005, s. 80-85.

9 Projekt noty KNP, 13 XI, nota polskiego MSZ z 22 XI, list z Lwowa do KNP z 25 XII 1918, PDD 1918, s. 9-11, 66, 353-354; K. Gałecki (polski przedstawiciel 
Wszystkie te czynniki decydowały, że Wiedeń nie był odbierany przez stronę polska jako ewentualny partner polityczny. Mógł co najwyżej pretendować do roli odbiorcy polskiego węgla, którego nad Dunajem zdecydowanie brakowało. Aczkolwiek Czesi blokowali dostawy z Polski, chcąc wywrzeć presję na Austrii. Pozostawało więc wytargowanie jak najwięcej dóbr materialnych i pieniędzy w negocjacjach dotyczacych likwidacji dualistycznej monarchii, w których udział brali także przedstawiciele innych państw sukcesyjnych ${ }^{10}$. Nie była to więc rola szczególnie ważna $z$ punktu widzenia Warszawy. Jednakże Adam Nowotny i Marceli Szarota (odpowiednio: polski przedstawiciel wojskowy i polski chargé d'affaires w Wiedniu) postrzegali Austrię jako miejsce rywalizacji mocarstw o uczynienie $z$ niej swojej strefy wpływów, tak politycznych, jak i gospodarczych (wykorzystanie kolei, wyzyskanie sił wodnych itp.). O ile w przypadku Francji i Włoch diagnoza ta była poprawna ${ }^{11}$, o tyle w przypadku

w Wiedniu do końca marca 1919 r.) do Paderewskiego, Wiedeń 8 II 1919, APIP, t. V, red. B. Janicka, Warszawa 2001, s. 28; Referaty informacyjne dla Naczelnego Dowództwa WP, 15 VIII i 1 IX, AAN, MSZ, teczka 215, k. 11, 22-24; Szarota do MSZ, Wiedeń XI 1920, APIP, t. VI, oprac. A.G. Dąbrowski et al., Warszawa 2007, s. 219-221.

${ }_{10}$ M. Zamoyski (poseł RP w Paryżu) do MSZ, Paryż 12 XII 1919, AAN, Ambasada RP w Paryżu [dalej: Amb. Paryż], teczka 36, k. 112-114. Polska delegacja, przygotowując się do negocjacji, zamierzała: wyliczyć straty ludności polskiej z powodu posiadania waluty austriackiej, rozdzielić majątek i rezerwy kas ubezpieczeniowych robotników, emerytów czy inwalidów wojennych, oszacować wartość austriackich kolei państwowych w obrębie terytorium przypadającego na Polskę w celu podziału udziałów w nich, doprowadzić do podziału majątku wojskowego, fabryk amunicji, zapasów broni i amunicji, co w niestabilnej na wszystkich granicach sytuacji mogło mieć poważne znaczenie, otrzymać udziały w rezerwach Banku Austro-Węgierskiego i pocztowych Kas Oszczędnościowych, wyliczyć straty wojenne pośrednie i bezpośrednie, by uzyskać za nie odszkodowania w walucie złotej lub w naturze, doprowadzić do rewindykacji zabytków kultury, a także do jak najkorzystniejszego dla siebie podziału długów Austro-Węgier - por. Wykaz ekspertyz zleconych przez Biuro Prac Kongresowych w związu Konferencja Pokojowa, przed 27 XII 1918, PDD 1918, s. 179-180.

11 Nowotny do MSWoj., Wiedeń $7 \mathrm{~V}$ i raport z Wiednia z $21 \mathrm{~V}$, AAN, KNP, teczka 50, k. 79-82; M. Loret (członek Misji KNP w Rzymie, a od 14 II 1919 r. przedstawiciel Rządu RP) do MSZ, Rzym 28 III, ibidem, teczka 104, k. 73-74; Zamoyski do MSZ, Paryż 15 XII, AAN, Amb. Paryż, teczka 36, k. 116; załącznik do raportu Zamoyskiego z 19 XII 1919 (ten sam dokument w AAN, MSZ, teczka 3674, k. 1-7, datowany na 20 XII 1919), ibidem, teczka 11, k. 30-37; odpisy raportów Szaroty, styczeń i 28 V, ibidem, teczka 223, k. 1-2, 4-6; AAN, Ambasada RP w Berlinie [dalej: Amb. Berlin], teczka 26, k. 21 V; Szarota do MSZ, Wiedeń 23 I, AAN, Ambasada RP w Londynie [dalej: Amb. Londyn], teczka 5, k. 56-57; przegląd polityczny nr 23 z 28 VI 1920, AAN, Poselstwo RP w Atenach, teczka 415, k. 33. 
mocarstw anglosaskich można ją śmiało nazwać zdecydowanie przesadzoną ${ }^{12}$.

Krajem o wiele bardziej interesującym dla Warszawy była Czechosłowacja - bezpośredni sąsiad południowy Polski. Państwo to było nad Wisła postrzegane jako słabe i wewnętrznie niespójne $z$ powodu licznych mniejszości narodowych. Polscy obserwatorzy zauważali postępująca centralizację władzy w Czechosłowacji i dominację pięciu partii czeskich, tworzących większość gabinetów czechosłowackich okresu międzywojennego (tzw. system "petki”, czyli piatki), mimo pozornie panujaccego systemu demokratycznego. W Warszawie zdawano sobie sprawę, że była to jedyna alternatywa pozwalająca uniknąc rozkładu kraju. Przy emancypacyjnych tendencjach Słowaków (według Alfreda Wysockiego, polskiego chargé d'affaires w Pradze, był to ruch za słaby dla zagrożenia jedności Czechosłowacji), którym nie podobała się dominacja Czechów; przy węgierskich roszczeniach rewizjonistycznych skierowanych pod adresem Rusi Zakarpackiej, południowej części Słowacji, a nawet całej tej krainy należącej historycznie do Korony Św. Stefana; przy ostrym separatyzmie Niemców mieszkających w Czechach Niemieckich, Kraju Sudeckim, południowych Morawach i Lesie Czeskim cała I Republika przysłowiowo trzeszczała w szwach ${ }^{13}$.

Strona polska nie bez satysfakcji patrzyła na napięcia wewnętrzne południowego sąsiada. Czechosłowacja była bowiem kolejnym

12 D. Jeziorny, German Austria - British Colony? An Episode of the British Policy towards Central Europe in 1919, [w:] The Role of Britain in the Modern World, eds K. Kujawińska-Courtney, R. Machnikowski, Łódź 1999, s. 177-193.

13 Inspektor policji granicznej (podpis nieczytelny) do niemieckiego Ministerstwa Spraw Wewnętrznych, Frankfurt nad Odra 6 XII 1919, AAN, Amb. Berlin, teczka 49, k. 1-2; P. Wandycz, Erazm Piltz a koncepcja polityki środkowoeuropejskiej, [w:] Międzymorze. Polska i kraje Europy Środkowo-Wschodniej XIX-XX wiek. Studia ofiarowane Piotrowi Łossowskiemu $w$ siedemdziesiata rocznice urodzin, Warszawa 1995, s. 220; wyciagi z raportów o sytuacji w Czechach z 17 VI i 6 VII, AAN, Amb. Londyn, teczka 55, k. 22ab, 30-31; wyciag z raportu Poselstwa Polskiego w Bernie z $7 \mathrm{X}$, ibidem, teczka 87, k. 10-12; referat informacyjny Naczelnego Dowództwa WP z 1 XII, AAN, MSZ, teczka 217, k. 132-134; L. Malczewski (sekretarz Poselstwa RP w Czechosłowacji) do MSZ, Praga 15 XII, ibidem, teczka 5439, k. 42-55; Malczewski do MSZ, Praga, 20 XI i Wysocki do MSZ, Praga 28 X 1920, ibidem, teczka 5442, k. 26-35. Por. A. Szklarska-Lohman nowa, Polsko-czechosłowackie stosunki dyplomatyczne $w$ latach 1918-1925, Wrocław 1967, s. 19-36, 121-124; P. Majewski, „Niemcy Sudeccy” 1848-1948. Historia pewnego nacjonalizmu, Warszawa 2007, 162-176, 188-192; D.E. Mi11er, Forging Political Compromise: Antonin Švehla and the Czechoslovak Republican Party. 1918-1933, Pittsburgh 1999, rozdz. II. 
nieprzyjaznym krajem, z którym odbudowująca się Rzeczpospolita miała konflikty. Oba państwa rywalizowały o rolę głównego partnera Ententy w Europie Środkowo-Wschodniej. W pierwszej fazie budowy obu państwowości wydawało się, że Praga miała przewagę $\mathrm{w}$ tym wyścigu, mając lepsze notowania w zachodnioeuropejskich stolicach i o wiele mniej groźnych przeciwników u swoich granic. Przyznawał to Erazm Piltz, działający w ramach Komitetu Narodowego Polskiego w Paryżu ${ }^{14}$.

Oprócz sporu o pierwszeństwo $\mathrm{w}$ regionie między Warszawą a Praga toczyły się konflikty graniczne. Przede wszystkim chodziło o przynależność Śląska Cieszyńskiego i znajdujących się w tym regionie kopaln. Polacy argumentowali, że stanowili na spornym terytorium Karwiny i Pietwałdu najliczniejsza grupę narodowościową, lecz nie udało im się osiągnąć pożądanego dla siebie rozwiązania metodą pokojową. Czesi wykorzystali słabość państwa polskiego i jego konflikty na wschodnich rubieżach oraz nieustępująca po zawarciu pokoju presję Niemiec. Czując, że Czechosłowacji nie grozi jakikolwiek rewanż, zajęli sporne tereny z Zaolziem na czele ${ }^{15}$.

Co więcej, dążąc do jeszcze większego osłabienia Polski, Praga wspierała Zachodnioukraińską Republikę Ludową w jej konflikcie zbrojnym $z$ Polakami. Jednym $z$ narzędzi było nadanie Ukraińcom w Rusi Zakarpackiej autonomii. Celem tego typu działań było niedopuszczenie przejęcia Galicji Wschodniej przez wojska polskie, co otwierało szanse Czechosłowacji na posiadanie bezpośredniej granicy z Ukraina, a raczej z Rosja, na co Praga wyraźnie miała ochotę, pragnąc pełnić funkcję pomostu między Wschodem a Zachodem ${ }^{16}$.

${ }^{14}$ S.M. Now in ow ski, Stosunki polsko-czechosłowackie u progu drugiej wojny światowej. Bilans otwarcia, [w:] Między przymusowa przyjaźnia a prawdziwa solidarnością. Czesi - Polacy - Słowacy 1938/39-1945-1989, Warszawa 2007, s. 13; D. Jezi or ny, Raporty znad Wełtawy - narodziny Czechosłowacji widziane oczami Cecila Goslinga, [w:] Czechosłowacja w stosunkach międzynarodowych $w$ pierwszej połowie XX w. Studia i szkice, red. A.M. Brzeziński, Warszawa 2003, s. 8-22; P. Wandycz, Erazm Piltz..., s. 219.

15 Statystyki demograficzne z czerwca, AAN, Delegacja Polska na Konferencje Pokojowa w Paryżu, teczka 45, k. 1-3, 6; instrukcja dla szefów polskich misji dyplomatycznych z 7 VII 1919, APIP, t. II, s. 254-255; A. Es sen, Polska a Mała Ententa 1920-1934, Warszawa-Kraków 1992, s. 25; A. Szklarska-Lohmannow a, op. cit., rozdz. II. Najszerzej na ten temat M.K. Ka mińs ki, Konflikt polsko-czeski 1918-1921, Warszawa 2001.

16 Referat informacyjny Naczelnego Dowództwa WP z 1 IX, AAN, MSZ, teczka 215, k. 22-24; referat informacyjny Naczelnego Dowództwa WP z 15 XI 1920, ibidem, teczka 217, k. 155. Szerzej: K. Lew a nd ow ski, Sprawa ukraińska w polityce zagranicznej Czechosłowacji w latach 1918-1932, Wrocław 1974, rozdz. II-III; 
W ten sam sposób należy interpretować tendencje Czechów do znalezienia kontaktów z Białorusinami i Litwinami. Szczególnie ta druga możliwość odbierana była w Warszawie $z$ ogromna niechęcią. Konflikt $z$ Litwą oznaczał bowiem nie tylko kolejnego wrogiego sassiada Rzeczypospolitej, lecz także fiasko koncepcji federacyjnej, która w swoim zamiarze miała przecież odsunięcie jak najdalej niebezpieczeństwa, wywołanego bliskością Rosji, niezależnie, czy byłaby to Rosja „biała”, czy „czerwona” 17 .

Wspomnieć wypada również wroga Polsce propagandę mająca swe źródło w Czechosłowacji. W tym względzie przodowali narodowi socjaliści (nie należy mylić $z$ niemieckimi nazistami!), którzy starali się nadać możliwie najszerszy rozgłos swoim tezom o chaosie panującym w Rzeczypospolitej mogącym zaowocować wybuchem bolszewizmu, o egoistycznym polskim „imperializmie”, o wręcz szowinistycznej nietolerancji Polaków wobec innych narodowości, o przestarzałym modelu społecznym, w którym dominująca rolę odgrywała zacofana szlachta, o nadmiernych wpływach Kościoła rzymskokatolickiego itp. ${ }^{18}$ Celem tych działań było uczynienie wizerunkowi Polski jak największej szkody, tak w samej Czechosłowacji, jak i w całej Europie.

Rząd Rzeczypospolitej z niechęcią patrzył na postępy zbrojeniowe południowej sąsiadki. Wiązały się one $z$ dostawami pochodzacymi $z$ austriackich arsenałów i fabryk (głównie Wiener Neustadt). Majacc w zanadrzu możliwość wywierania presji polegającej na szantażowaniu Austriaków dostarczaniem lub niedostarczaniem węgla, Praga skutecznie zapewniała sobie potrzebne materiały wojenne oraz nie dopuszczała, aby znalazły się one w rękach innych potrzebujących ich państw, jak choćby Rzeczypospolitej ${ }^{19}$.

P. W andycz, France and her Eastern Allies 1919-1925. French-Czechoslovak-Polish Relations from the Paris Peace Conference, Minneapolis 1962, s. 107-111; A. Es s e n, op. cit., s. 16-18.

${ }_{17}^{17}$ P. Wandycz, Erazm Piltz..., s. 221.

18 S.M. Nowinowski, Polska $w$ dyplomacji czechosłowackiej 1926-1932, Łódź 2013, s. 10-17. Przykłady propagowania przez Czechów niechętnych Polsce treści w państwach zachodnich w: Departament Wywiadu Politycznego Foreign Office, raport w sprawach słowiańskich, 1 IV (tutaj o antyżydowskich poczynaniach Polaków), The National Archives, Londyn, Foreign Office 371/4373/589, 600; uwagi Lewisa B. Namiera (pracownik Departamentu Wywiadu Politycznego) z 20 I 1919, ibidem 371/3896, nr 5255. Por. odbiór działań Pragi przez stronę polską w K. Świtalski, Diariusz 1919-1935, oprac. A. Garlicki, R. Świętek, Warszawa 1992, s. 65, wpis z 4 XI 1920.

19 Nota Sztabu Generalnego z 24 III 1919, AAN, KNP, teczka 104, k. 91; referaty informacyjne Naczelnego Dowództwa WP z 1 V i 15 VIII, AAN, MSZ, teczka 217, 
Na końcu listy punktów spornych wspomnieć należy o niekorzystnej dla Polski polityce neutralności w trakcie najdramatyczniejszych dla odbudowy kraju momentów zbliżania się bolszewików pod Warszawę. Praga ogłosiła neutralność 9 sierpnia 1920 r., a następnie nakłoniła do tego rządu Austrii. W efekcie Polska została odcięta od ewentualnych dostaw materiałów wojskowych $z$ Francji droga kolejowa, omijająca Niemcy, które nie ukrywały radości $z$ decyzji o nieprzepuszczeniu jakichkolwiek transportów do Polski $^{20}$. Oznaczało to osłabienie możliwości Warszawy stawienia czoła najeźdźcom.

Polskę i Czechosłowację dzieliło jeszcze jedno strategiczne przeciwieństwo. Wiosną 1920 r. Eduard Beneš, minister spraw zagranicznych I Republiki, rozpoczął starania o zbudowanie sojuszu $z$ Królestwem SHS. Mógłby on nie tylko umocnić oba kraje w obliczu możliwego konfliktu $z$ Węgrami, lecz także doprowadzić do przejęcia obszaru tzw. Węgier Zachodnich, zwanych przez Niemców Burgenlandem. Podzielenie tego terenu między siebie pozwalałoby nie tylko na bezpośrednia granicę i, co za tym szło, komunikację między zaprzyjaźnionymi krajami słowiańskimi. Olbrzymim atutem $z$ uzyskania takiego rozwiązania byłoby również trwałe rozdzielenie Austrii od Węgier, co na trwałe pogrą̇̇łoby ewentualność reaktywowania związku państwowego między obu dominujacymi w monarchii habsburskiej narodami. Praga widziała w takiej możliwości olbrzymie zagrożenie dla swojego bytu państwowego. Dyplomacja polska nie przywiązywała szczególnej wagi do tego typu rozwiązań. Natomiast próba przyciągnięcia przez ministra Beneša do współpracy antywęgierskiej dodatkowo Rumunii była już z punktu widzenia Warszawy groźna. Nad Wisłą obawiano się poważnie, że związanie się Bukaresztu z Pragą mogłoby negatywnie wpłynąć na polsko-rumuńskie współdziałanie przeciwko Rosji. Wydawało się ono kluczowe $z$ punktu widzenia przyszłego układu sił na wschodzie Europy. Dlatego też strona polska starała się jak najbardziej utrudnić kontakty Beneša $z$ rumuńskimi liberałami i konserwatystami, rywalizującymi między sobą o władzę w Bukareszcie, ażeby antywęgierska współpraca Rumunii z Czechosłowacja nie uniemoż-

k. 2, 47; wyciąg z raportu Poselstwa Polskiego, Wiedeń 23 IX 1920, AAN, Amb. Londyn, teczka 11, k. 79.

${ }^{20}$ D. Jeziorny, Międzynarodowe znaczenie Austrii w okresie rzadów Karla Rennera w ocenach dyplomacji polskiej, „Przegląd Zachodni” 2014, R. LXX, nr 2, s. 141. 
liwiła defensywnej kooperacji polsko-rumuńskiej przeciwko zagrożeniu ze wschodu ${ }^{21}$.

Złe stosunki Warszawy z Praga musiały skłaniać dyplomację polska do spojrzenia na inny kraj, który miał poważne konflikty z Czechosłowacją. Współpraca polsko-węgierska nie była jednak$\dot{z}$ e ani latwa, ani oczywista. Wszystko to $z$ powodu burzliwych wydarzeń rozgrywających się na Węgrzech. Niedługo po rozpadzie monarchii habsburskiej, 23 marca 1919 r. władzę w Budapeszcie przeją Bela Kun, który w swoich pierwszych deklaracjach ogłosił sojusz z Rosja bolszewicka. W Warszawie wywoływało to wrażenie otoczenia „zewsząd zalewem bolszewickim”. Miał nadzieję, że zbliżająca się na zachód rewolucyjna fala zmiecie wrogą wobec Węgrów Rumunię. Na nieszczęście dla Kuna pochód bolszewików na zachód został wiosna 1919 r. powstrzymany - wręcz doszło do skutecznej polskiej kontrofensywy na froncie wschodnim. O ile więc dla reżimu komunistycznego w Budapeszcie oznaczało to klęskę, o tyle dla relacji polsko-węgierskich otwierała się nowa przestrzeń do współpracy. Strona polska skrupulatnie monitorowała konflikty Węgrów o granice i była świadoma, jakie działania podejmowali oni na rzecz polepszenia swojego położenia. Nawiązywali współpracę $z$ chorwackimi federalistami Ivana Franki, ale jednocześnie $z$ Włochami w celu osłabienia czy wręcz rozbicia tworzącego się Królestwa SHS. W Polsce zauważano przy okazji, że cele polityczne Chorwatów i Włochów były nie do pogodzenia. Celem rozbicia Czechosłowacji Węgrzy utrzymywali także kontakty ze słowackimi ludakami księdza Andreja Hlinki, z którymi również Polacy inicjowali współpracę. Osłabienie Czechosłowacji było zamiarem zarówno Budapesztu, jak i Warszawy. Mimo ostrej retoryki antybolszewickiej głoszonej w obu krajach w 1920 r. polscy wojskowi nie zatajali prawdy, że kryła się za nią chęć współdziałania nie przeciwko Rosji, lecz przeciwko Czechosłowacji ${ }^{22}$.

${ }^{21}$ Referat informacyjny Naczelnego Dowództwa WP z 8 XII 1919, AAN, MSZ, teczka 6896, k. 35; memorandum dyrektora Departamentu Dyplomatycznego MSZ z 20 VIII, AAN, Amb. Paryż, teczka 9, k. 20; referat informacyjny Naczelnego Dowództwa WP z 1 IX 1920, AAN, MSZ, teczka 215, k. 19-22; E. de W e is s, Dispute for Burgenland in 1919, „Journal of Central European Affairs” 1943, vol. III, No. 2, s. 150-165; W. Stę pniak, Dyplomacja polska na Bałkanach (1918-1926), Warszawa 1998, s. 74-75; H. Bułhak, Poczatki sojuszu polsko-rumuńskiego i przebieg rokowań o konwencje wojskowa w latach 1919-1921, „Dzieje Najnowsze" 1973, R. V, z. 3, s. 22-23.

${ }^{22}$ W. Wróblewski (wiceminister spraw zagranicznych) do KNP, Warszawa 25 II 1919, oraz meldunek Jerzego Potockiego (polski attaché wojskowy w Budapesz- 
Polska dyplomacja uzyskała również informację o współpracy władz węgierskich $z$ austriacką Partią Chrześcijańsko-Społeczna, pozostająca w tym okresie w opozycji wobec rządu Karla Rennera. Ten chciał odnieść choć jeden sukces terytorialny w zmaganiach o powojenne granice swojego kraju, a taka szansa wydawał się tylko jedna: przejęcie Burgenlandu, wchodzącego od 1647 r. w skład Zalitawii. Skazywało to Wiedeń na konflikt z Budapesztem i wspó1pracę $z$ Praga, dążąca do wyizolowania Węgier, a nawet $z$ Bukaresztem. W roku 1920 napięcie między obu krajami było tak duże, że polscy dyplomaci nie wykluczali wojny, szczególnie że dochodziło incydentów granicznych, jak choćby węgierska napaść na austriacki magazyn broni w Fürstenfeld. Na większą konfrontację jednakże żadna ze stron się nie zdecydowała, gdyż nie była ona tak naprawdę ich celem. Strona polska monitorowała tę płaszczyznę sporu, lecz nie była nia bezpośrednio zainteresowana. Po przegranych przez austriackich socjaldemokratów wyborach z 19 października $1920 \mathrm{r}$. nowy rząd Michaela Mayra bardzo szybko poprawił relacje $z$ zachodnim sąsiadem, ale bynajmniej nie za cenę zrzeczenia się spornego terytorium. O jego losach zadecydował ostatecznie plebiscyt w komitacie Sopron 14-16 grudnia 1921 r., który przypadł Wegrom ${ }^{23}$.

Najgorzej $z$ polskiego punktu widzenia wyglądała sytuacja $\mathrm{w}$ relacjach węgiersko-rumuńskich. Dla Warszawy współpraca $z$ Bukaresztem przeciwko Rosji Sowieckiej i Zachodnioukraińskiej Republice Ludowej warta była czasowego poświęcenia spornych terenów Pokucia $^{24}$. Przedstawiała więc wartość naprawdę wielką i stąd wynikało dążenie do sformalizowania współpracy bilateralnej. Dyplomacja polska śledziła na bieżąco rozwój konfliktu rumuńsko-węgierskiego o ziemie Siedmiogrodu, Maramuresz i Banatu. W tym kontekście pojawiały się nawet idee, ażeby próbować mediować

cie), Polskie dokumenty dyplomatyczne 1919: styczeń-maj [dalej: PDD 1919: styczeń-maj], red. S. Dębski, Warszawa 2016, s. 357, 564-565; Wyciagi z raportów Poselstwa RP w Belgradzie z 6 i 8 V 1920, AAN, Amb. Londyn, teczka 66, k. 15, 18.

${ }^{23}$ D. Jeziorny, Międzynarodowe znaczenie..., s. 154-155; Szarota do MSZ, Wiedeń 23 I i 25 IX, AAN, Amb. Londyn, teczka 5, k. 56-62; MSZ do E. Sapiehy (od 16 VI 1919 poseł polski w Londynie, a od 23 VI 1920 r. szef MSZ), Warszawa 7 i 12 III, ibidem, teczka 11, k. 75-78; referat informacyjny Naczelnego Dowództwa WP z 15 X 1920, AAN, MSZ, teczka 228, k. 21; T. S pira, The Sopron (Ödenburg) Plebiscite of December 1921 and the German Nationality Problem, [w:] War and Society in East Central Europe, vol. VI (Essays on World War I: Total War and Peacemaking. A Case Study on Trianon), eds B.K. Király, P. Pastor, I. Sanders, New York 1982, s. 322.

${ }^{24}$ W. Stępniak, op. cit., s. 48-50, 54-55, 78-80. 
w celu wyciszenia sporu obu tych sąsiadów i nakłonić ich do kolaboracji przeciwko wspólnym przeciwnikom. Pojawiły się w tym kontekście nawet efemeryczne pomysły unii personalnej między obu krajami. Apetyty na rozwiązanie problemów węgiersko-rumuńskich w myśl rozładowania napięcia między nimi mogła zaostrzyć wizja dobrych relacji Budapesztu z Brytyjczykami i Francuzami (tutaj zwolennikiem postawienia na Węgry był Maurice Paléologue, lecz przegrał rywalizację o stanowisko sekretarza generalnego na Quai d'Orsay). Jeszcze latem 1920 r. wydawała się ona bardzo bliska osiagnięcia. Pomijając to, że pomysł ten pozostawał raczej odległym od realizacji marzeniem ze względu na poziom temperatury sporu, taka linia polityczna nie uzyskała jednoznacznego poparcia w szeregach polskich dyplomatów. Solidaryzowali się z nią Jan Szembek (poseł w Budapeszcie) i Marceli Szarota. Część natomiast uznawała, że niemożliwe było występowanie ręka w rękę $z$ pokonanymi w czasie I wojny światowej Węgrami przeciwko Czechosłowacji, protegowanej Francji, która z kolei dla Polski była najważniejsza sojuszniczką. Taki punkt widzenia, podkreślający równocześnie nierealność namówienia Węgrów i Rumunów do porzucenia wrogości wzajemnej, wyrażali Erazm Piltz i Zygmunt Stefański (odpowiednio: polski poseł i chargé d'affaires w Belgradzie) ${ }^{25}$. Sprawa była o tyle bardziej skomplikowana, że Włochy nie akceptowały powstania na północ od swoich granic jakiegokolwiek bloku uniemożliwiającego im ekspansję i zwiększanie wpływów polityczno-gospodarczych na terenie Europy Środkowej. Wciągnięcie Węgier do współpracy z Polską i Rumunią, które w oczywisty sposób skłaniały się ku Francji, było więc dla Rzymu nie do przyjęcia ${ }^{26}$.

Ostatecznie więc nie udało się Warszawie doprowadzić do wyciszenia konfliktów na linii Bukareszt-Budapeszt, a te powodowały

${ }^{25}$ Zamoyski do MSZ, Paryż, 19 XII 1919, AAN, Amb. Paryż, teczka 11, k. 30 wyciag $z$ raportu Poselstwa RP w Budapeszcie, Budapeszt 7 VIII,; AAN, Amb. Londyn, teczka 41, k. 5-8; Piltz do Sapiehy, Paryż po 6 VIII, APIP, t. II, s. 452-453; referaty informacyjne Naczelnego Dowództwa WP z 1 V i 15 X, AAN, MSZ, teczka 224, k. 4, 12; referaty informacyjne Naczelnego Dowództwa WP z 1 V i 1 XII 1920, ibidem, teczka 228, k. 9-10, 18-19; P. W andycz, Erazm Piltz..., s. 220-224; J. Łaptos, Kształtowanie sie francuskiej koncepcji konfederacji naddunajskiej $w$ latach 1918-1920, „Zeszyty Naukowe Uniwersytetu Jagiellońskiego. Prace Historyczne” 1991, z. 97, s. 68-71.

${ }^{26}$ D. Jeziorny, Londyn a spuścizna po monarchii Habsburgów. Sprawa Austrii w koncepcjach i praktyce dyplomatycznej Wielkiej Brytanii (1918-1919), Torun 2002, s. 165; S. Sierpowski, Stosunki polsko-włoskie w latach 19181940, Warszawa 1975, s. 215-216. 
zbliżenie rumuńsko-czechosłowackie. W następnych miesiącach strona polska ograniczała się do monitorowania sytuacji wewnętrznej w Rumunii, która daleka była od stabilizacji. Konflikty wewnętrzne między skłóconymi konserwatystami a liberałami, problemy $z$ traktowaniem mniejszości narodowych, szczególnie Żydów, a także kwestia integracji przyłączonych po I wojnie światowej terenów, zwiększających powierzchnię kraju dwukrotnie sprawiały osłabionemu wojna państwu sporo problemów ${ }^{27}$. Polityka zagraniczna Bukaresztu wcale nie była jednoznaczna - wstrzymywanie się $z$ podpisaniem układu sojuszniczego $z$ Polską aż do zawarcia pokoju polsko-rosyjskiego to jeden $z$ przykładów potwierdzających tę tezę. Dla rządu w Warszawie nie tylko zresztą współpraca polityczno-wojskowa odgrywała kluczowa rolę. Bardzo istotna dla strategicznego położenia państwa polskiego była kwestia tranzytu przez Rumunię ewentualnej pomocy dla Polski. Polscy wojskowi, po negatywnych doświadczeniach $z$ czasów wojny polsko-bolszewickiej, nie mieli złudzeń co do możliwości liczenia w razie zagrożenia na tranzyt koleja francuskiej pomocy przez terytorium Szwajcarii, Austrii i Czechosłowacji. Próbowali więc obmyślić inne trasy kolejowe do Polski z Triestu i z Braiły na wybrzeżu Morza Czarnego. Pierwsza $z$ nich miała dokładnie te same niedogodności, co droga przez Szwajcarię, ponieważ wiodła przez Austrię i Czechosłowację ${ }^{28}$. Natomiast druga wiodłaby przez o wiele bardziej przyjazna Polsce Rumunię. Jej minusem był jednakże brak porządnej, dwutorowej linii kolejowej biegnącej $z$ portu w kierunku granicy $z$ Polską ${ }^{29}$. Tym niemniej względy strategiczne nakazywały Warszawie osiągnąc sojusz wojskowy oraz wspólną granicę $z$ Rumunią, $z$ którą wiązały Polskę „ogromnie istotne interesa", jak to wyraził Władysław Wróblewski ${ }^{30} . Z$ oczywistych względów geograficznych rozwiązanie to wykluczało czechosłowacki pomysł sąsiadowania z Ukraińcami lub Rosją.

${ }^{27}$ A. Kas tory, Rozbiór Rumunii w 1940 roku, Warszawa 2002, s. 10-24.

${ }^{28}$ W późniejszych latach polscy sztabowcy wojskowi obmyślali skierowanie tranzytu $z$ Triestu do Polski przez Banat i dalej przez terytorium Rumunii. Wymagało to jednak poważnych inwestycji w rozbudowę sieci kolejowej i stworzenie odpowiedniego mostu na Dunaju.

${ }^{29}$ Naczelne Dowództwo WP do gen. T. Rozwadowskiego (szef polskiej Misji Wojskowej w Paryżu), Warszawa 26 IV 1919, AAN, MSZ, teczka 236, k. 9; W. Stępniak, op. cit., s. 115-116, 250-251.

${ }^{30}$ Wróblewski do Poselstwa RP w Sofii, Warszawa 22 II, notatka MSZ z 12 IV oraz Komisja Likwidacyjna KNP do Paderewskiego, Paryż 22 IV 1919, PDD 1919: styczeń-maj, s. 326, 625-627, 680-681. 
Najmniej znacząca z punktu widzenia Warszawy była rola Królestwa SHS. Wpływ na to miała odległość między obu krajami. Tym niemniej w Polsce zdawano sobie sprawę ze wszystkich słabości tego kraju: wrogość sąsiadów, którzy dążyli do odebrania spornych terytoriów (Włochy, Albania, Węgry, Austria, Grecja i Bułgaria, a nawet Rumunia w przypadku Banatu), a także wewnętrzna niespójność. Składały się na nią spory między Serbami a innymi narodowościami, głównie Chorwatami, o model państwa - pierwsi chcieli centralizmu, drudzy federalizmu. Ponadto istotnym konfliktem wewnętrznym była sprawa czarnogórskiej rodziny królewskiej wspieranej z Rzymu. Stabilność Królestwa SHS miała jednakże znaczenie $z$ powodu planowanego uczynienia $z$ Triestu portu tranzytowego przewożącego artykuły do Polski. Groźne mogły być również prorosyjskie inklinacje Belgradu (w Serbii stacjonowała duża kolonia „białych” emigrantów, czego jednakże Warszawa nie odczytywała jako antypolskich tendencji). Ponadto Słowianie południowi niejednokrotnie oglądali się na Niemców, szukając w nich pomocy przeciwko ekspansji włoskiej, a Niemcy mogli to w przyszłości wykorzystywać w rozgrywkach $z$ Polska. Jednakże pierwsze kontakty dyplomatyczne były bardzo serdeczne. Przybywajacy do Belgradu 6 stycznia 1919 r. Czesław Pruszyński usłyszał od przyjmującego jego listy uwierzytelniajace Mihailo Gavrilovicia ciepłe słowa. Pełniący funkcję szefa dyplomacji serbskiej dyplomata wyraził wobec pierwszego polskiego chargé d'affaires wolę nawiąania ,jak najściślejszego kontaktu pomiędzy wszystkiemi pobratyńczemi narodami słowiańskiemi" ${ }^{31}$.

Podsumowując, należy stwierdzić, że basen naddunajski, w którym położone były państwa sukcesyjne powstałe na gruzach Austro-Węgier, był bardzo istotnym dla rodzacej się Rzeczypospolitej terenem. Stąd też dyplomaci i wojskowi polscy na bieżąco monitorowali sytuację w regionie Europy Środkowej, czego ślady zachowały się $\mathrm{w}$ archiwum mimo ogromnych zniszczeń spowodowanych przez II wojnę światową. Liczba zachowanych źródeł z roku 1920 jest zdecydowanie większa niż z dwóch poprzednich lat. Tym niemniej

${ }^{31}$ Pruszyński do MSZ, Belgrad 15 I 1919, PDD 1919: styczeń-maj, s. 72; Raporty attachatu wojskowego w Belgradzie z 1 IX 1919 i 30 V, 6 i 22 VI oraz 31 VII, AAN, Ambasada RP Londyn, teczka 66, k. 2-4, 25, 30-32, 35-38, 42-43; referaty informacyjne Naczelnego Dowództwa WP z 1 i 15 VII, 15 IX oraz 1 XII, AAN, MSZ, teczka 222, k. 10-11, 25, 46, 64; referat informacyjny Naczelnego Dowództwa WP z 1 VIII 1920, ibidem, teczka 221, k. 14; W. Stępniak, op. cit., s. 140-143, 147-149. 
daje to wyobrażenie o wadze państw sukcesyjnych dla Polski. Należy jednakże zauważyć, że mimo ogromnego zainteresowania dyplomacja polska nie była dopuszczona do współdecydowania o losach tego regionu na Konferencji Pokojowej w Paryżu, co było domeną wielkich mocarstw. Po drugie, Czechosłowacja, Austria, Węgry, Rumunia i Królestwo SHS to jednak nie region pierwszorzędnej wagi. O wiele istotniejsi $z$ punktu widzenia Warszawy byli sassiedzi na wschodzie i na zachodzie. Po prostu polska niepodległość, bezpieczeństwo i integralność terytorialna zależały od stosunków $z$ Niemcami i Rosją. Dlatego też aktywniejsza polityka w obszarze naddunajskim możliwa był dopiero po uporaniu się $z$ niebezpieczeństwem ze wschodu latem i jesienia $1920 \mathrm{r}$.

Polacy prowadzili na tyle aktywna politykę wobec państw sukcesyjnych Austro-Węgier, na ile było to możliwe. Przede wszystkim brali aktywny udział $\mathrm{w}$ negocjacjach dotyczacych podziału dóbr państwowych, pozostałych po rozkładzie dualistycznej monarchii. W drugiej kolejności Warszawa poszukiwała sojuszników wśród państw powstałych na gruzach monarchii habsburskiej. Na pierwszy plan wysuwała się $\mathrm{w}$ tym względzie współpraca $z$ Rumunią, uwieńczona w marcu 1921 r. sukcesem w postaci układu sojuszniczego, skierowanego przeciwko Rosji. Próby współdziałania antyczechosłowackiego $z$ Budapesztem nigdy się nie zmaterializowały. Warszawa obrała linię ograniczonej i trudnej współpracy z Małą Ententą przy zachowaniu możliwie jak najlepszych relacji z Węgrami. Na początku lat dwudziestych w obliczu ogromnej niestabilności w Europie nie do wyobrażenia było występowanie przeciwko bliskiej sojuszniczce Francji. Nie zmieniała tego nastawienia nieprzyjazna wobec Warszawy polityka Pragi, tak na płaszczyźnie politycznej, jak i propagandowej. Jedyne, na co sobie dyplomacja polska pozwalała, to pogłębianie trudności i niesnasek w szeregach Małej Ententy.

Dość specyficzne miejsce w polityce polskiej lat 1918-1920 zajmowała Austria, której słabość polityczną i ekonomiczną doskonale widziano w Warszawie. Dzięki temu rzą polski pozwalał sobie na oskarżenia pod adresem Wiednia, że wywołał walki we Lwowie oraz wspierał emigracyjny ośrodek władzy Zachodnioukraińskiej Republiki Ludowej. Propagandowo więc zmagania o Galicję Wschodnią nabierały charakteru walki członka Ententy z popieranymi przez wroga Austrię Ukraińcami. Jednak nie eksploatowano tego wątku nadmiernie, ażeby nie osłabiać i tak już stojącej na skraju upadku republiki. W Warszawie obawiano się możliwości wchłonięcia 
Austrii do Niemiec, co zwiększałoby potencjał zachodniego sąsiada, jak również odtworzenia w jakiejś formie Austro-Węgier, które zapewne byłyby silniejszym podmiotem niż odradzająca się Rzeczpospolita. Co ciekawe jednak, polscy wojskowi uznawali Wiedeń za główne centrum intryg na europejska skalę. Był to pogląd zdecydowanie przesadzony.

Ostatnia refleksja dotyczy najważniejszej arterii komunikacyjnej Europy Środkowej, Dunaju. Umiędzynarodowieniem tej rzeki interesowały się mocarstwa i kraje leżące nad jego brzegami. Każdy $z$ podmiotów zamierzał osiagnąć jak najkorzystniejsze warunki wykorzystania Dunaju do celów żeglugowych, handlowych i obronnych. Co ciekawe, krajem, który wyłamywał się z grupy zainteresowanych, była Polska. Przedstawiciele Warszawy uczestniczyli wprawdzie w rokowaniach Komisji ds. Dunaju, lecz nie zabiegali o jakieś szczególne uprawnienia dla siebie $z$ tego powodu, że rzeka płynęła $z$ zachodu na wschód, ale nie była żeglowna od terytorium Francji. Nisko oceniane były ponadto: stan floty handlowej na Dunaju, brak fachowców oraz materiałów do naprawy ${ }^{32}$. O wiele istotniejsze były więc $\mathrm{w}$ tym wypadku linie kolejowe o przebiegu południkowym, łączące Polskę $z$ portami w Braile i Trieście.

\section{Bibliografia}

\section{$\dot{\mathbf{Z}}_{\text {RÓDEA ARCHIWALNE }}$}

Archiwum Akt Nowych w Warszawie

Ambasada RP w Berlinie, teczki 26, 49.

Ambasada RP w Londynie, teczki 5, 11, 41, 55, 66, 87.

Ambasada RP w Paryżu, teczki 9, 11, 27, 36, 223.

Attachaty, AII/56.

Delegacja Polska na Konferencję Pokojową w Paryżu, teczka 45.

Komitet Narodowy Polski, teczki 50, 104.

${ }^{32}$ Szembek do MSZ, Budapeszt 26 XII, AAN, Amb. Paryż, teczka 27, k. 18-29; referat informacyjny dla Naczelnego Dowództwa WP z 1 V, AAN, MSZ, teczka 222, k. 7; referat informacyjny dla Naczelnego Dowództwa WP z 15 XII 1920, ibidem, teczka $215, \mathrm{k} .50-51$. W jednym $z$ raportów $z$ Wiednia głoszono, że Francuzi mieli chęć wybudowania kanału łączącego Odrę i Wisłę z Dunajem, co uczyniłoby $z$ nich arterię komunikacyjna między Polską a Zachodem, ale doniesienia tego typu wydają się zdecydowanie zbyt optymistyczne - por. raport z $21 \mathrm{~V} \mathrm{1919,} \mathrm{AAN,}$ KNP, teczka 50, k. 83-84. 
Ministerstwo Spraw Zagranicznych, teczki 215, 217, 221, 222, 224, 228, 236, 5439, 5442, 6896.

Poselstwo RP w Atenach, teczka 415.

The National Archives, Londyn, Foreign Office 371: 3896, 4373.

\section{Ź RÓDEA DRUKOWANE}

Archiwum Polityczne Ignacego Paderewskiego, t. II, oprac. W. Stankiewicz, Warszawa 1976; t. V, red. B. Janicka, Warszawa 2001; t. VI, oprac. A.G. Dąbrowski et al., Warszawa 2007.

O niepodległa i granice. Komitet Narodowy Polski. Protokoły posiedzeń 1917-1919, oprac. M. Jabłonowski, D. Cisowska-Hydzik, Warszawa-Pułtusk 2007.

Polskie dokumenty dyplomatyczne 1919: styczeń-maj, red. S. Dębski, Warszawa 2016.

Polskie dokumenty dyplomatyczne 1918: listopad-grudzień, red. S. Dębski, Warszawa 2008.

Świtalski K., Diariusz 1919-1935, oprac. A. Garlicki, R. Świętek, Warszawa 1992.

Wandycz P., Erazm Piltz a koncepcja polityki środkowoeuropejskiej, [w:] Międzymorze. Polska i kraje Europy Środkowo-Wschodniej XIX-XX wiek. Studia ofiarowane Piotrowi Łossowskiemu $w$ siedemdziesiata rocznice urodzin, Warszawa 1995, s. 215-225.

\section{Prasa}

„Czas” 1918.

\section{Opracowania}

Bułhak H., Poczatki sojuszu polsko-rumuńskiego i przebieg rokowań o konwencje wojskowa w latach 1919-1921, „Dzieje Najnowsze” 1973, R. V, z. 3, s. 7-24.

Essen A., Polityka Czechosłowacji w Europie Środkowej w latach 1918-1932, Kraków 2006.

Essen A., Polska a Mała Ententa 1920-1934, Warszawa-Kraków 1992.

Fest W., Peace or Partition. The Hapsburg Monarchy and British Policy. 1914-1918, London 1978.

Jeziorny D., Austria kanclerza Karla Rennera (1918-1920) w raportach polskich dyplomatów i wojskowych, [w:] Austria i relacje polsko-austriackie w XX i XXI wieku. Polityka - kultura - gospodarka, red. A. Kisztelińska-Węgrzyńska, K.A. Kuczyński, Łódź, 2014, s. 67-83.

Jeziorny D., German Austria - British Colony? An Episode of the British Policy towards Central Europe in 1919, [w:] The Role of Britain in the Modern World, eds K. Kujawińska-Courtney, R. Machnikowski, Łódź 1999, s. 177-193.

Jeziorny D., Londyn a spuścizna po monarchii Habsburgów. Sprawa Austrii w koncepcjach i praktyce dyplomatycznej Wielkiej Brytanii (1918-1919), Toruń 2002. 
Jeziorny D., Międzynarodowe znaczenie Austrii w okresie rząów Karla Rennera w ocenach dyplomacji polskiej, „Przeglad Zachodni” 2014, R. LXX, nr 2, s. $139-158$.

Jeziorny D., Raporty znad Wełtawy - narodziny Czechosłowacji widziane oczami Cecila Goslinga, [w:] Czechosłowacja $w$ stosunkach międzynarodowych w pierwszej połowie XX w. Studia i szkice, red. A.M. Brzeziński, Warszawa 2003, s. 8-22.

Kamiński M.K., Konflikt polsko-czeski 1918-1921, Warszawa 2001.

Kastory A., Rozbiór Rumunii w 1940 roku, Warszawa 2002.

Lewandowski J., Królestwo Polskie wobec Austro-Wegier 1914-1918, WarszawaŁódź 1986.

Lewandowski K., Sprawa ukrainska $w$ polityce zagranicznej Czechosłowacji w latach 1918-1932, Wrocław 1974.

Łaptos J., Kształtowanie sie francuskiej koncepcji konfederacji naddunajskiej w latach 1918-1920, „Zeszyty Naukowe Uniwersytetu Jagiellońskiego. Prace Historyczne" 1991, z. 97, s. 57-78.

Majewski P., „Niemcy Sudeccy” 1848-1948. Historia pewnego nacjonalizmu, Warszawa 2007.

Miller D.E., Forging Political Compromise: Antonin Švehla and the Czechoslovak Republican Party. 1918-1933, Pittsburgh 1999.

Nowinowski S.M., Konstatacje i nadzieje. Dyplomacja czechosłowacka wobec kwestii bezpieczeństwa zbiorowego w Europie (1918-1925), Torun 2005.

Nowinowski S.M., Polska w dyplomacji czechosłowackiej 1926-1932, Łódź 2013.

Nowinowski S.M., Stosunki polsko-czechosłowackie u progu drugiej wojny światowej. Bilans otwarcia, [w:] Między przymusowa przyjaźnia a prawdziwa solidarnością. Czesi - Polacy - Słowacy 1938/39-1945-1989, Warszawa 2007, s. 12-17.

Pajewski J., Odbudowa państwa polskiego 1914-1918, Warszawa 1985.

Parafianowicz H., Czechosłowacja $w$ polityce Stanów Zjednoczonych $w$ latach 1918-1933, Białystok 1996.

Perman D., The Shaping of Czechoslovak State. Diplomatic History of the Boundaries of Czechoslovakia, 1914-1920, Leiden 1962.

Sierpowski S., Stosunki polsko-włoskie w latach 1918-1940, Warszawa 1975.

Spira T., The Sopron (Ödenburg) Plebiscite of December 1921 and the German Nationality Problem, [w:] War and Society in East Central Europe, Vol. VI. Essays on World War I: Total War and Peacemaking. A Case Study on Trianon, eds B.K. Király, P. Pastor, I. Sanders, New York 1982, s. 321-341.

Stępniak W., Dyplomacja polska na Bałkanach (1918-1926), Warszawa 1998.

Stolper G., Deutsch-Österreich als Sozial- und Wirtschaftsproblem, Wien 1921.

Szklarska-Lohmannowa A., Polsko-czechosłowackie stosunki dyplomatyczne w latach 1918-1925, Wrocław 1967.

Świętek R., Lodowa ściana. Sekrety polityki Józefa Piłsudskiego, 1904-1918, Kraków 1998

Wandycz P., France and her Eastern Allies 1919-1925. French-Czechoslovak-Polish Relations from the Paris Peace Conference, Minneapolis 1962.

Weiss E. de, Dispute for Burgenland in 1919, „Journal of Central European Affairs” 1943, vol. III, No. 2, s. 147-166. 


\title{
The successor states of the Austro-Hungarian Empire in the Polish diplomacy (1918-1920)
}

\begin{abstract}
A ustria, Hungary, Czechoslovakia, Romania, the Kingdom of SCS and Poland are the countries referred to as successor states of the Habsburg Monarchy since they were established out of its ruins. This article focuses on how meaningful these Central European states were to Polish diplomacy in 1918-1920, i.e. the period which was decisive in the creation of their independent existence. The aim of the article is to answer the question of how the gradual breakup of the unitary Austria-Hungary in 1918 was perceived by the Polish political elites. It will also examine what stance the government of the independent Polish state adopted towards the new countries that were being formed after the dissolution of the Habsburg Monarchy. All the states which were fully or partially composed of the former Austro-Hungarian territories are considered with the exception of Italy which was already recognised as one of the most important European powers and after its annexation of the Habsburg lands on the Adriatic Sea was even more of a power. The article will also explore whether the emerging countries played any role in the development of Polish foreign policy and if so, how significant this role was. A similar question can be asked in the case of the entire territory of the Danube Region. After the First World War, its political and economic unity was shattered, which could have been used by the nascent Poland while dealing with its weaker partners.
\end{abstract}

Keywords: Polish diplomacy, Austro-Hungarian successor states, Danube Region. 